\title{
Regarding the Analysis of Tension and Deformation States In Case Of High Speed Cutting Turning
}

\author{
Mihai Ţălu ${ }^{1}$, Daniel Popescu ${ }^{2}$, Roxana Cristina Popescu ${ }^{3,4}$ \\ ${ }^{I}$ (University Of Craiova, Romania) \\ ${ }^{2}$ (University Of Craiova, Romania) \\ 3 ("Horia Hulubei" National Institute for Physics and Nuclear Engineering, Romania) \\ ${ }^{4}$ (Politehnica University Of Bucharest, Romania)
}

\begin{abstract}
This paper contains an analysis of the stress and deformation states in case of high speed cutting turning: the normal unitary stress, the tangent unitary stress, the unitary stress in the main inertia direction, resulting linear deformation, resulting angular deformation, self vibration modes. Based on this information, the quality of the cutting surface can be improved by optimizing the working parameters.
\end{abstract}

Keywords: deformation, high speed cutting turning, self vibration modes, stress

\section{Introduction}

It is known the fact that, in the actual context, high speed cutting assures a series of advantages, among which we recall: increase of productivity, no modifications of the surface structure during the processing, high surface quality, allows the processing of highly rough materials, in many cases the finishing is obtained directly from turning, by eliminating the rectification, increasing the lifetime of the tools, reduced processing forces, superior dimensional precision and an increased reproducibility in the series production. At the same time, a series of opportunities appear: the final processing of a large variety of parts with minimal energy costs and harmful air emissions. By eliminating about $85 \%$ of the heat produced during the cutting, the surface is minimally influenced by the minimum remanent tensions, the increase of the cutting speed determining a decrease of the roughness of the processed surface. Some risks also appear: the intense cutting mode can lead to dynamic phenomena like vibrations, which have negative effects upon the quality of the as-processed surfaces. From this reason, the analysis of the tension and deformation states, in regards of the determination of proper vibration modes, is really important.

\section{Materials and experimental procedure}

During the cutting technological process, some complex surface phenomena appear at the contact between the cutting part of the tool and the part. The processing of the surface is influenced by a large series of factors bringing the cumulative influence, stimulated or not by the presence of other determining factors. We recall the ensemble and local deformation state of the piece, of the tool, the thermal processes, the rigidity of the system, the vibration mode and behavior during the whole dynamic movement in the elastic system cutting process $[1,3,4,5]$.

The parameters influencing the high speed cutting will be taken into consideration: the tool with particleboards, the material which will be processed, the geometry of the surface which will be processed, the work advances, the cutting depth, the type of the processing machine tool $[1,3]$. The simulation was done using SolidWorks 2016 software (Dassault Systems, Waltham, Massachusetts, USA). In order to make the spatial modeling of the tool-piece ensemble, the following parameters were taken: no $=3000 \mathrm{rot} / \mathrm{min} ; \mathrm{s}=0.32 \mathrm{~mm} /$ rot; $\mathrm{t}=0.35 \mathrm{~mm} ; \mathrm{vr}=228.59 \mathrm{~m} / \mathrm{min} ; \mathrm{P}=1.5 \mathrm{~kW}$.

In order to make the Finite Element analysis, it is necessary to make the ensemble of cutting toolpiece, which are in contact during the cutting process, at the depth and advance cutting calculated for the finishing operation [2]. We also take into consideration the positioning and the surfaces contact, in concordance with the longitudinal advance direction during the cutting and the rotation direction of the piece [2].

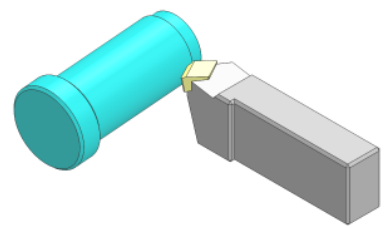

Fig. 1. Tool-piece model for exterior cilindrical cutting 


\section{Results of finite element analysis}

3.1 NORMAL STRAIN STATE

Since the main strains occur in the contact zone between the carbide cutting plate and the workpiece, the images obtained from the analysis will be focused in this area. The normal strain state is presented in fig. $2-5$ with the following values::

$\sigma_{\mathrm{rez}}=153.1 \mathrm{MPa}, \sigma_{\mathrm{x}}=49.54 \mathrm{MPa}, \sigma_{\mathrm{y}}=46.82 \mathrm{MPa}, \sigma_{\mathrm{z}}=45.03 \mathrm{MPa}$.

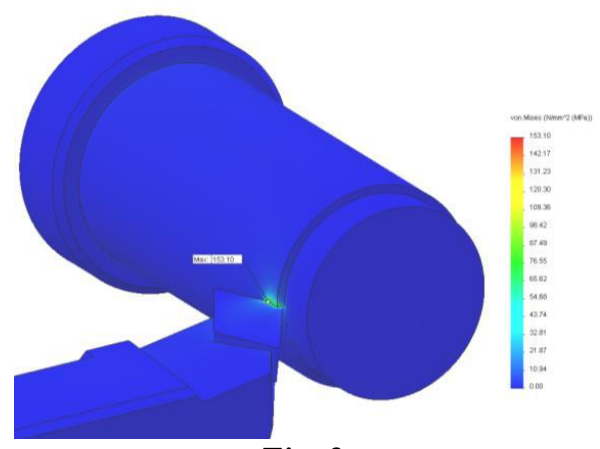

Fig. 2.

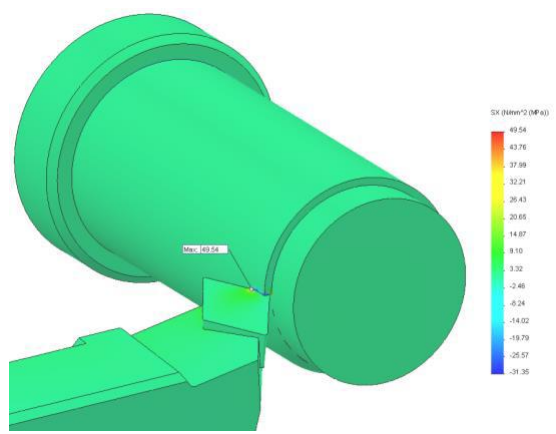

Fig.3.

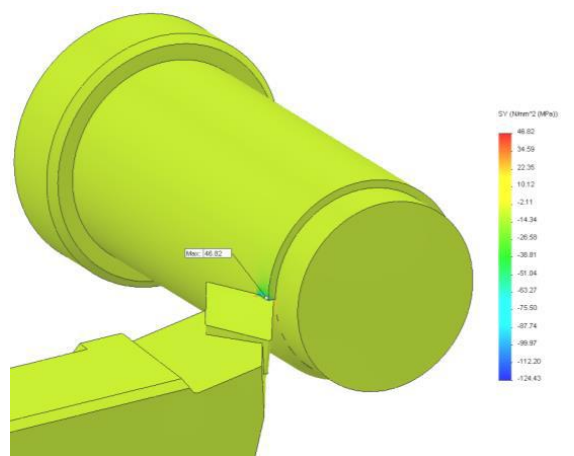

Fig. 4.

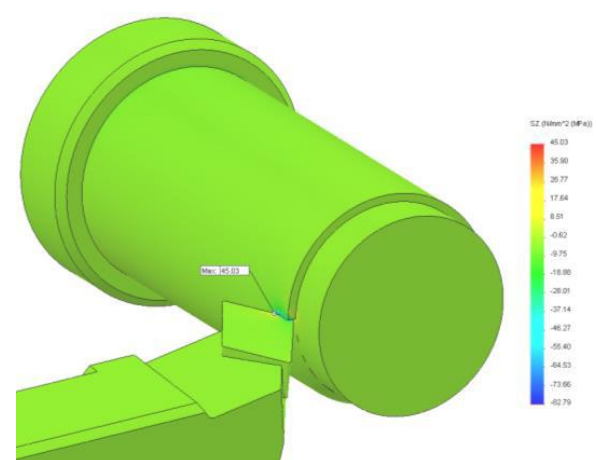

Fig. 5. 


\subsection{TANGENTIAL STRAIN STATE}

Tangential unit stress values are presented in fig. 6,7 and 8; they have the following values: $\tau \mathrm{xy}=27.41 \mathrm{MPa}$; $\tau \mathrm{XZ}=45.66 \mathrm{MPa}$ $\tau \mathrm{Z}=22.11 \mathrm{MPa}$

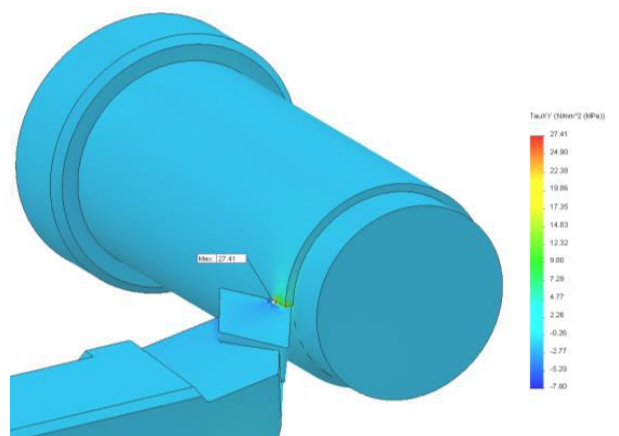

Fig. 6.

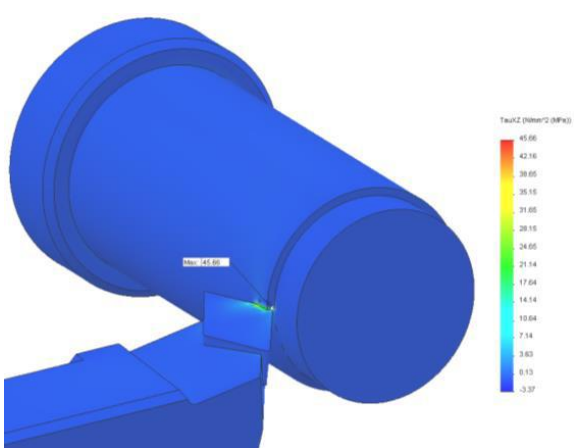

Fig. 7.

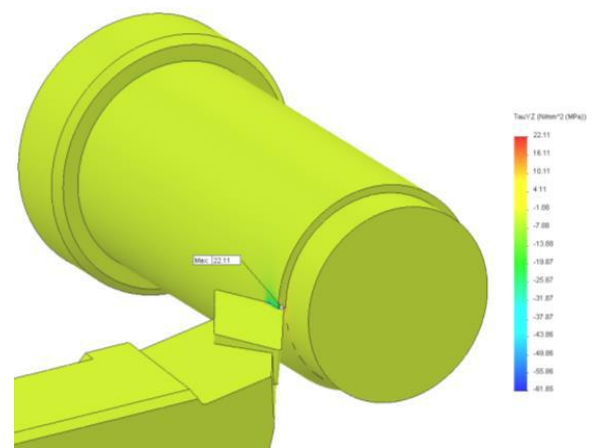

Fig. 8 .

\subsection{MAXIMUM UNIT STRAIN IN MAIN INERTIAL DIRECTIONS}

The unit strain values in the main inertial axes are presented in fig. $9-12$ :

$\sigma_{\text {rez }}=165.64 \mathrm{MPa}$;

$\sigma_{\mathrm{P} 1}=85.67 \mathrm{MPa}$;

$\sigma_{\mathrm{P} 2}=29.67 \mathrm{MPa}$;

$\sigma_{\mathrm{P} 3}=10.57 \mathrm{MPa}$;

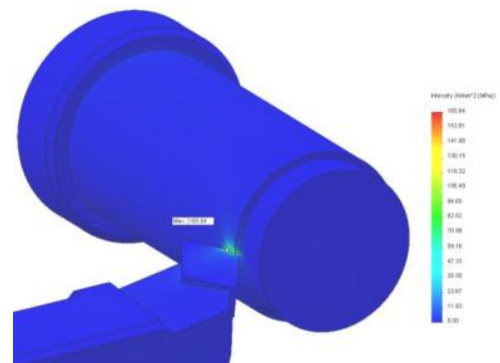

Fig. 9. 


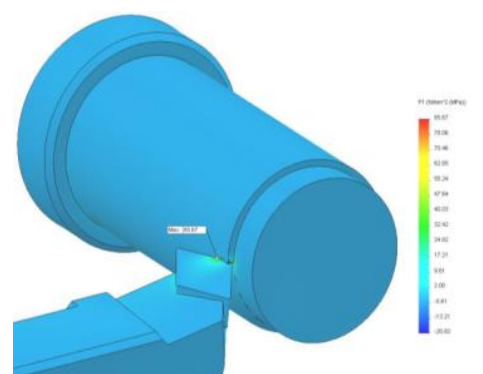

Fig. 10.

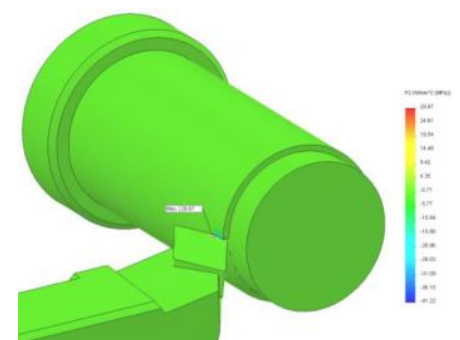

Fig. 11.

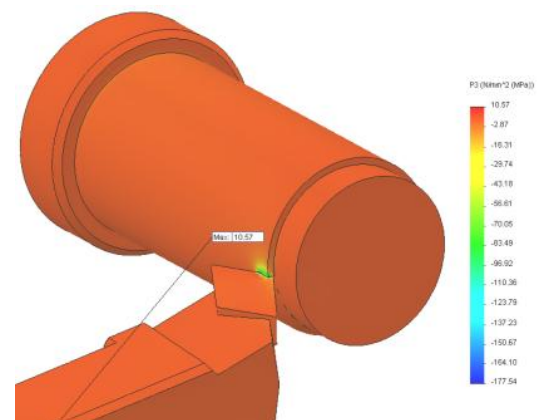

Fig. 12.

\subsection{LINEAR DEFORMATION STATE}

The linear deformation values for all axes is presented in fig. 13 - 16:

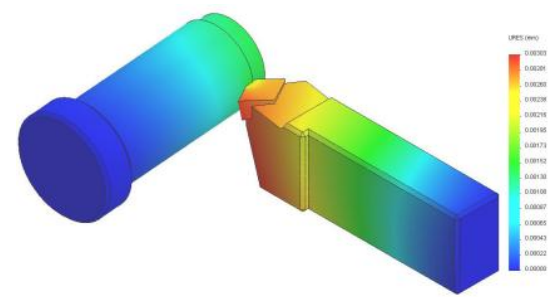

Fig. 13. Resulting linear deformation, urez $=0.00303 \mathrm{~mm}$;

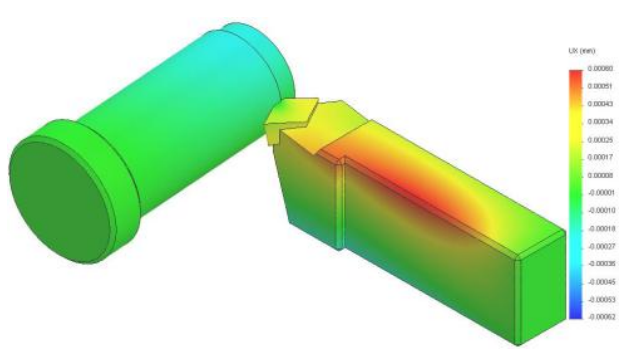

Fig. 14. Linear deformation on $X$ axis, $u x=0.00060 \mathrm{~mm}$. 


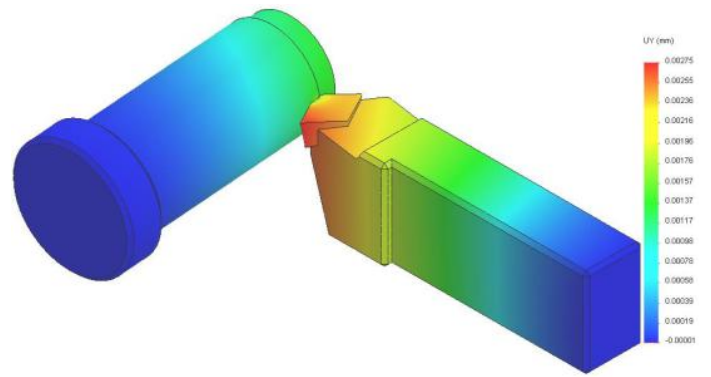

Fig. 15. Linear deformation on Y axis, $u y=0.00275 \mathrm{~mm}$;

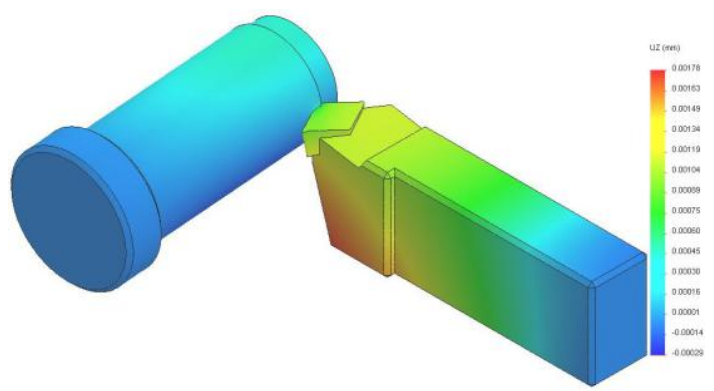

Fig. 16. Linear deformation on $Z$ axis, $u z=0.00178 \mathrm{~mm}$;

\subsection{ANGULAR DEFORMATION STATE OF THE SHAPE, $\varepsilon$}

The angular deformation $\varepsilon$ is presented in fig. $17-20$ :

$$
\begin{aligned}
& \varepsilon \mathrm{rez}=7.62510^{-4} \mathrm{rad} ; \\
& \varepsilon \mathrm{x}=2.71410^{-4} \mathrm{rad} ; \\
& \varepsilon \mathrm{y}=1.56310^{-5} \mathrm{rad} ; \\
& \varepsilon \mathrm{z}=1.18310^{-4} \mathrm{rad}
\end{aligned}
$$

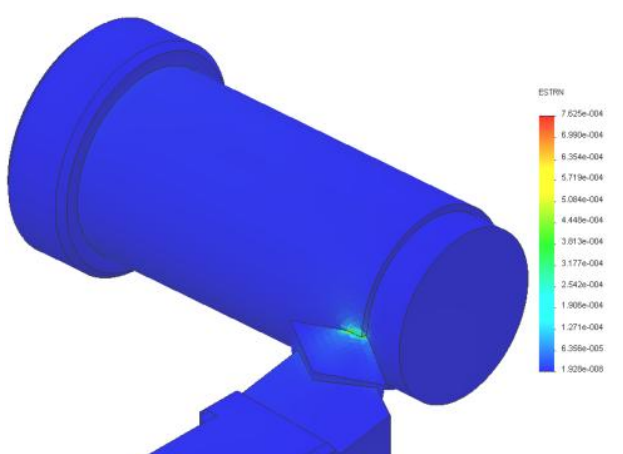

Fig. 17

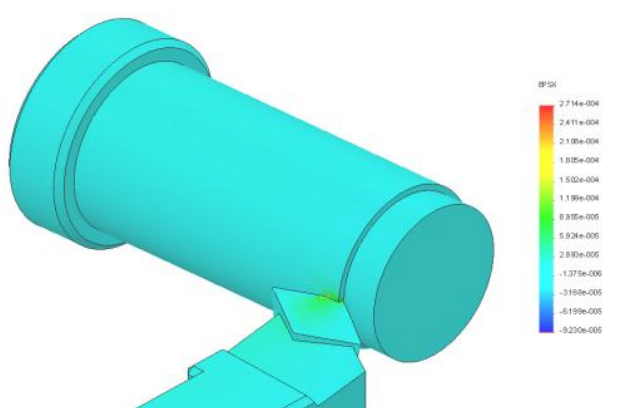

Fig. 18 


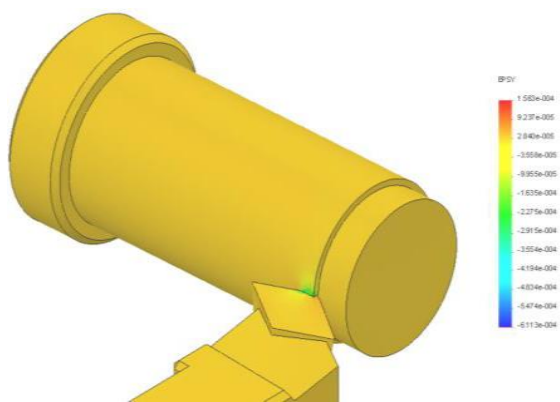

Fig. 19

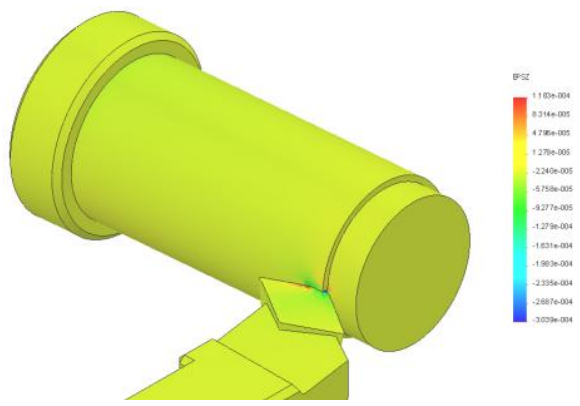

Fig. 20

\subsection{ANGULAR DEFORMATION STATE OF THE SHAPE, $Y$}

The angular deformation $\gamma$ of the shape is presented in fig. $21-23$ with the following values:

$$
\begin{aligned}
& \gamma \mathrm{xy}=4.87910^{-4} \mathrm{rad} ; \\
& \gamma \mathrm{xz}=6.3910^{-4} \mathrm{rad} ; \\
& \gamma \mathrm{yz}=2.28410^{-4} \mathrm{rad} ;
\end{aligned}
$$

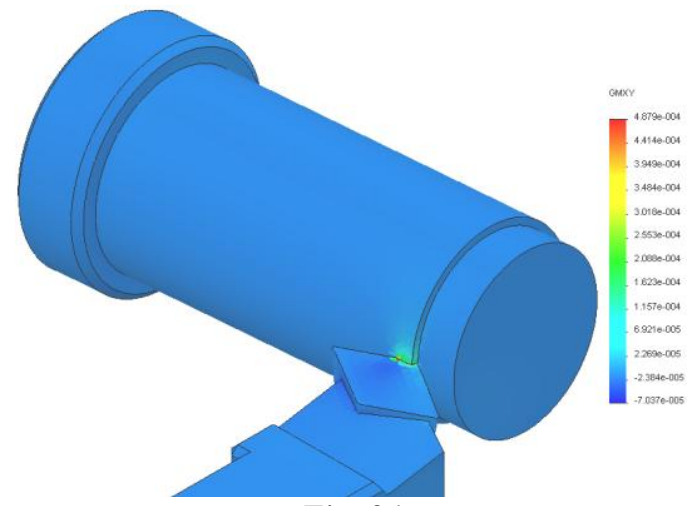

Fig. 21

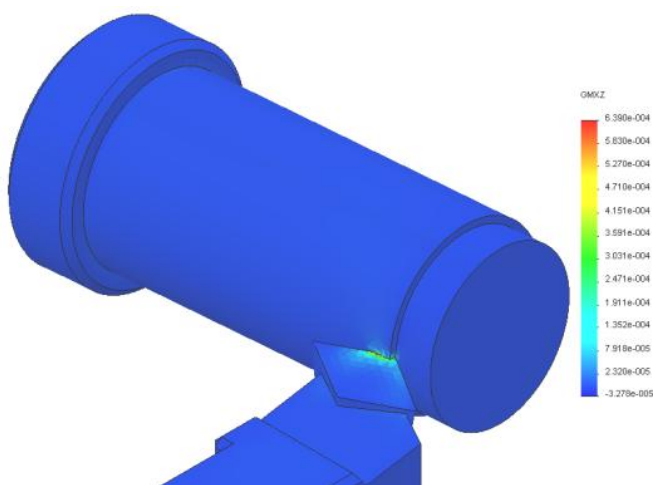

Fig. 22 


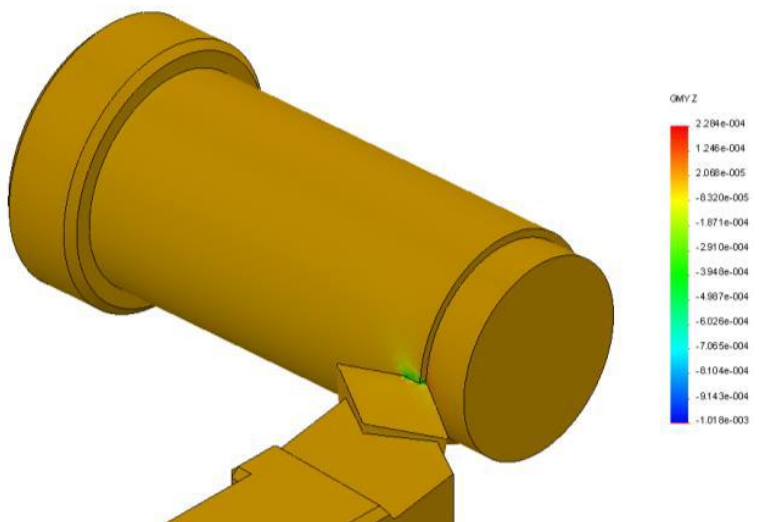

Fig. 23

\subsection{COMPUTATION OF PROPER VIBRATION MODES}

Given the dynamic nature of the cutting process, in which maintained vibrations are generated, it is useful to analyze the proper vibration modes of the tool - piece system.

The computed vibration frequencies for the first ten vibration modes are presented in Table 1.

Table 1.

\begin{tabular}{|c|c|c|c|}
\hline $\begin{array}{c}\text { Mode } \\
\text { no. }\end{array}$ & $\begin{array}{c}\text { Frequency } \\
(\mathrm{rad} / \mathrm{s})\end{array}$ & $\begin{array}{c}\text { Frequency } \\
(\mathrm{Hz})\end{array}$ & $\begin{array}{c}\text { Period } \\
(\mathrm{s})\end{array}$ \\
\hline 1 & 26007 & 4139.1 & 0.0002416 \\
\hline 2 & 26169 & 4164.9 & 0.0002401 \\
\hline 3 & 36325 & 5781.2 & 0.00017297 \\
\hline 4 & 46293 & 7367.7 & 0.00013573 \\
\hline 5 & 63848 & 10162 & $9.8409 \mathrm{e}-005$ \\
\hline 6 & 83028 & 13214 & $7.5675 \mathrm{e}-005$ \\
\hline 7 & 90768 & 14446 & $6.9223 \mathrm{e}-005$ \\
\hline 8 & $1.0501 \mathrm{e}+005$ & 16713 & $5.9833 \mathrm{e}-005$ \\
\hline 9 & $1.1103 \mathrm{e}+005$ & 17672 & $5.6588 \mathrm{e}-005$ \\
\hline 10 & $1.2726 \mathrm{e}+005$ & 20254 & $4.9374 \mathrm{e}-005$ \\
\hline
\end{tabular}

The deformation states for the computed proper vibration modes is presented in fig. $24-33$ :

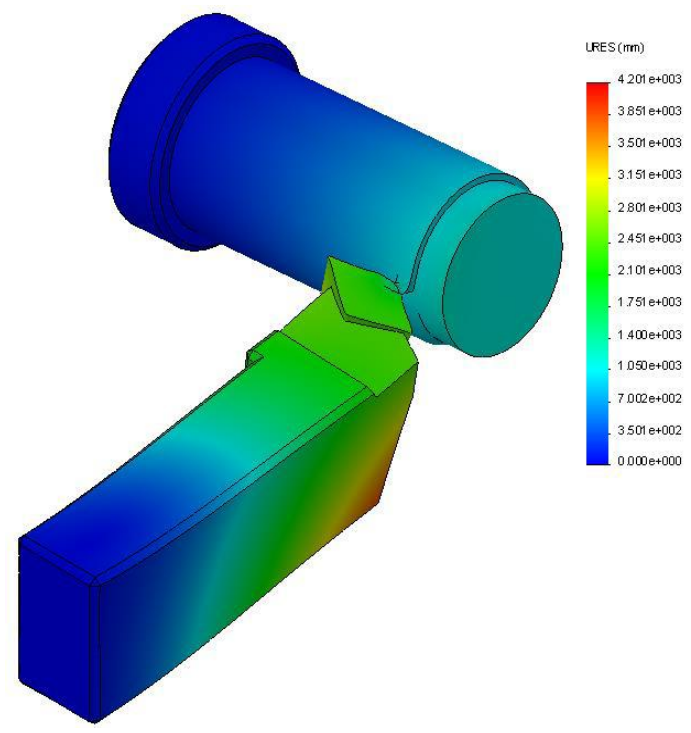

Fig. 24. Proper vibration mode I; $v=4139.1 \mathrm{~Hz}$ 


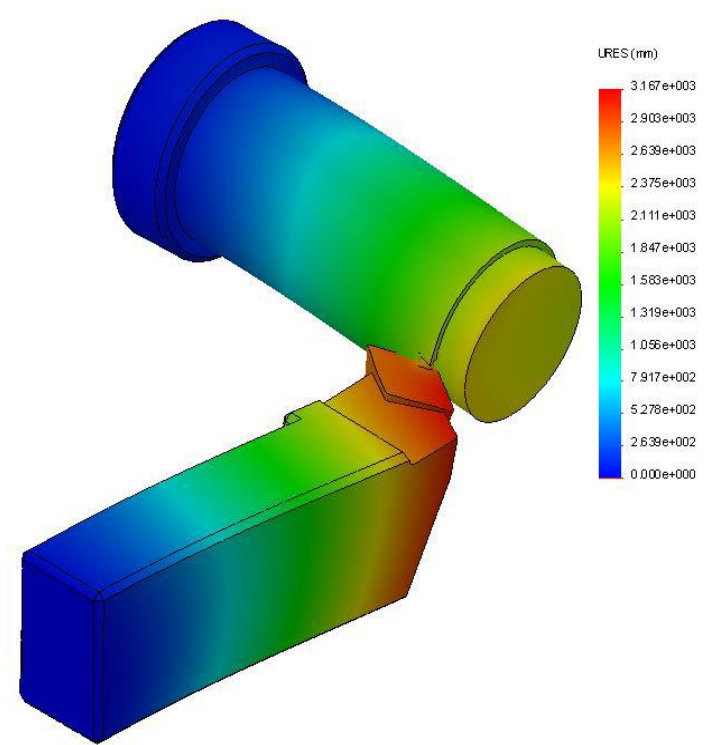

Fig. 25. Proper vibration mode II; $v=4164.9 \mathrm{~Hz}$

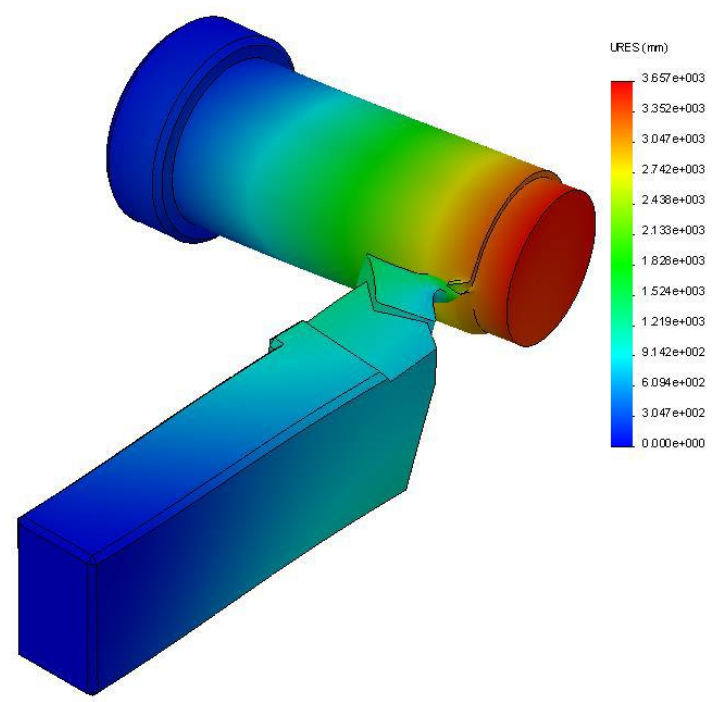

Fig. 26. Proper vibration mode III; $v=5781.2 \mathrm{~Hz}$

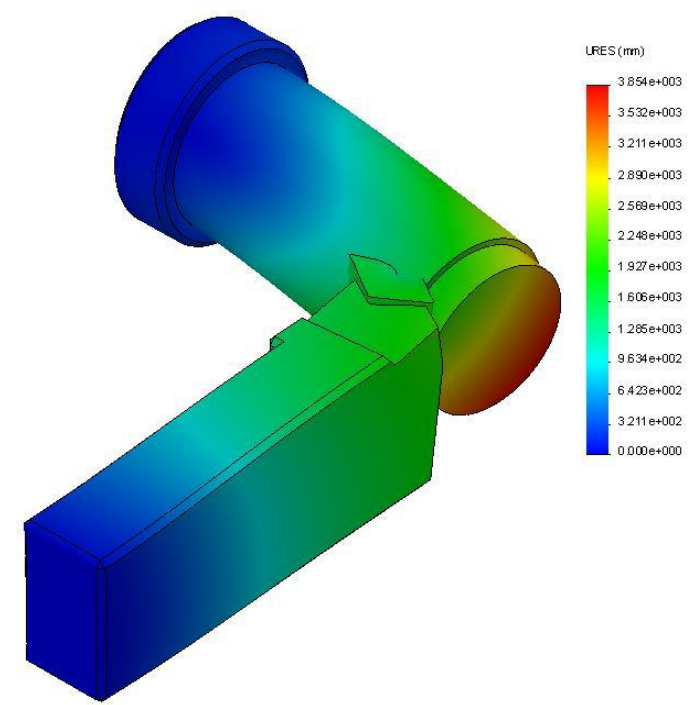

Fig. 27. Proper vibration mode $I V ; v=7367.7 \mathrm{~Hz}$ 


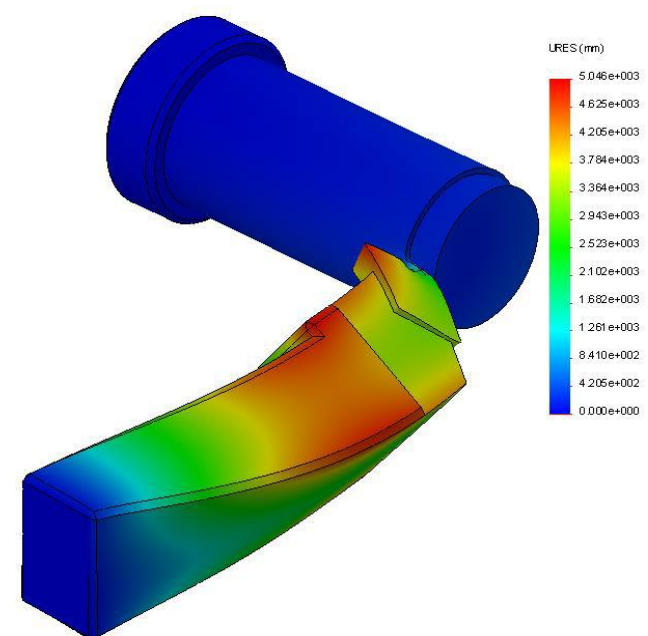

Fig. 28. Proper vibration mode $V ; v=10162 \mathrm{~Hz}$

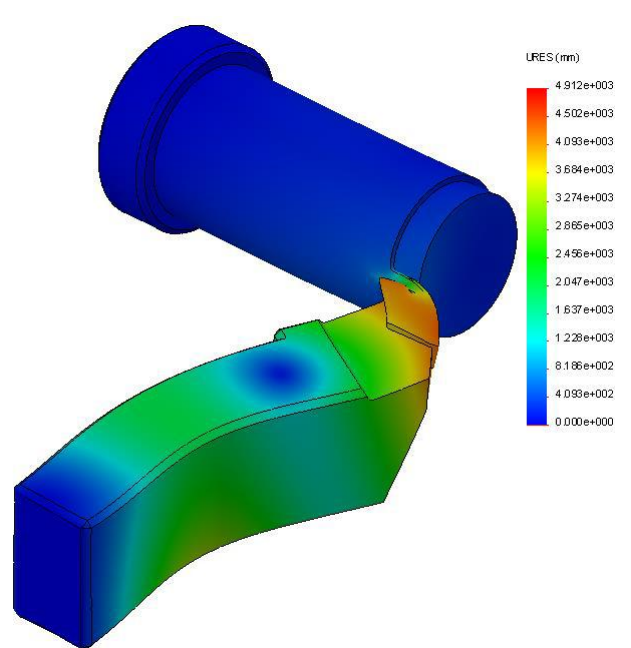

Fig. 29. Proper vibration mode VI; $v=13214 \mathrm{~Hz}$

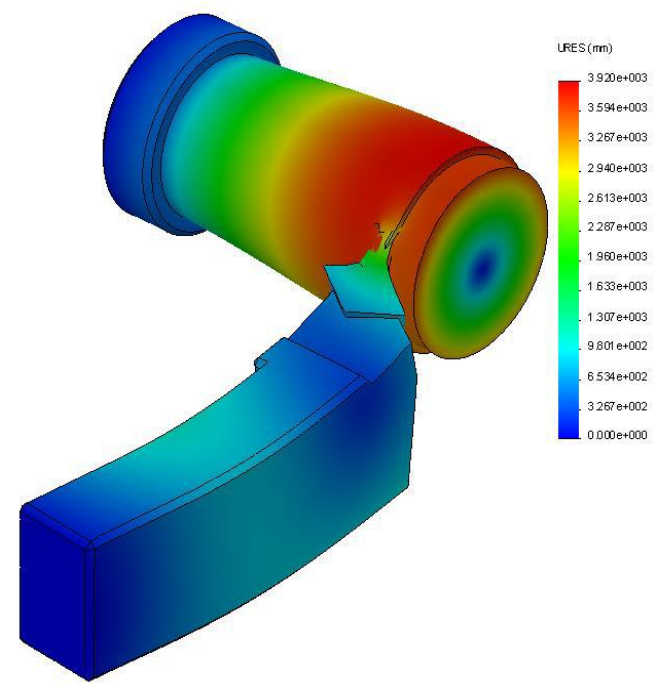

Fig. 30. Proper vibration mode VII; $v=14446 \mathrm{~Hz}$ 


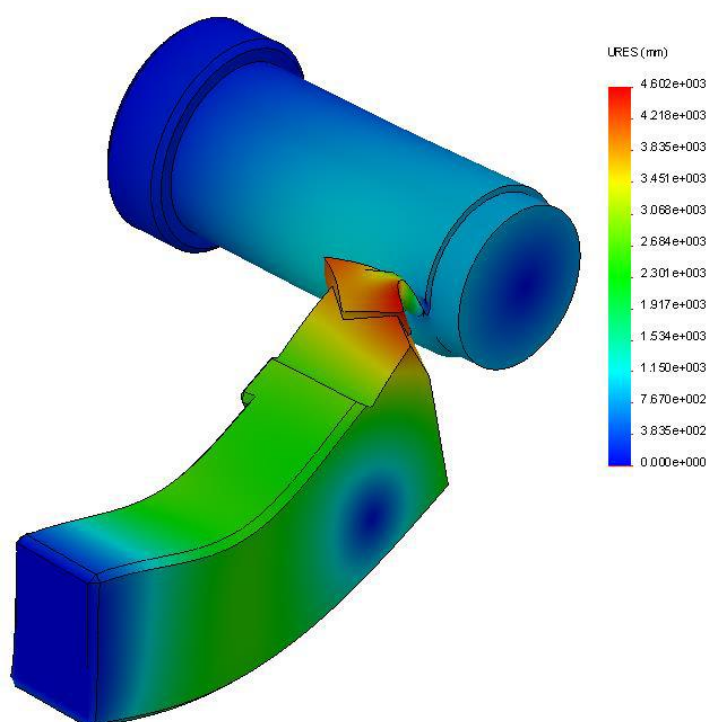

Fig. 31. Proper vibration mode VIII; $v=16713 \mathrm{~Hz}$

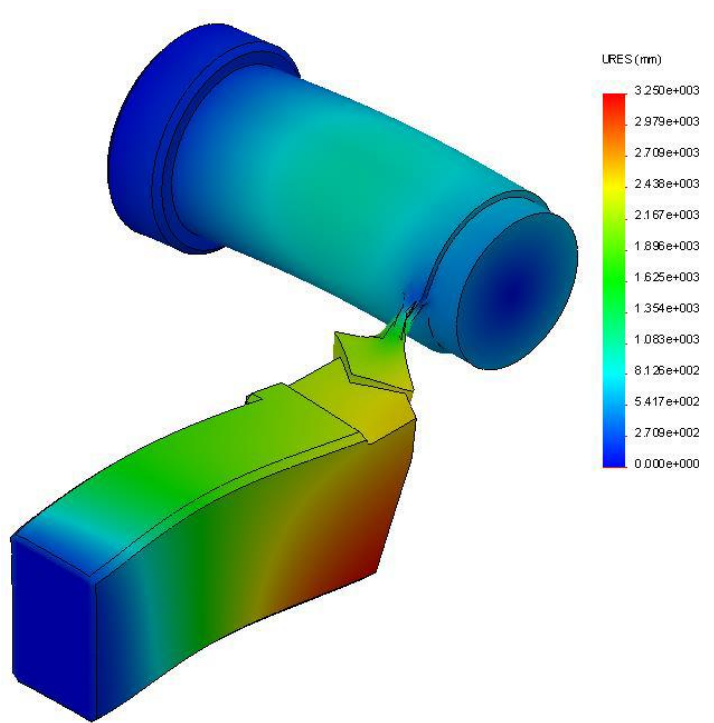

Fig. 32. Proper vibration mode IX; $v=17672 \mathrm{~Hz}$

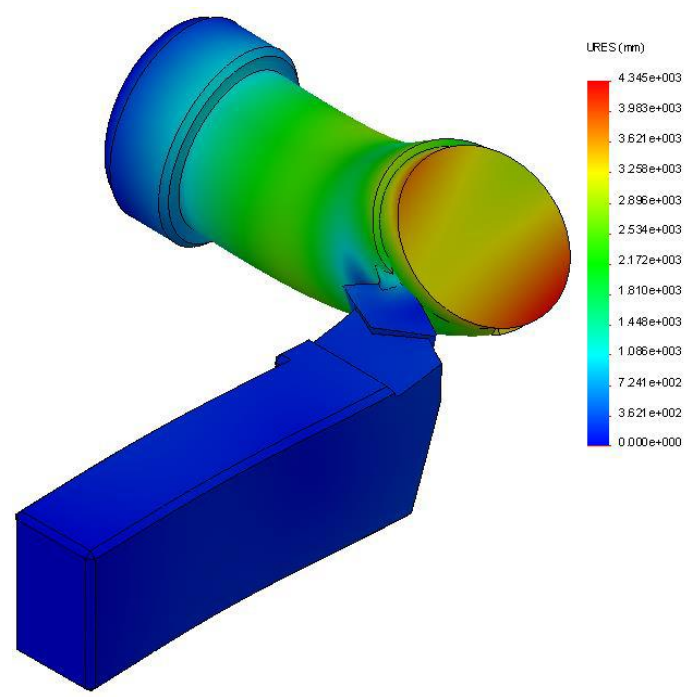

Fig. 33. Proper vibration mode $X ; v=20254 \mathrm{~Hz}$ 


\section{Conclusion}

From the analysis of strain, deformation and vibration states of the semi-finished piece and cutting tool ensemble that occur in cutting turning of external cylindrical surfaces, the following conclusions can be drawn:

- The active part of the knife is exposed to the largest strains and deformations.

- The contact area between the cutting part of the knife and the chip part of the piece is the subject to the largest deformation, both linear and angular.

- It can be observed that the deformation component value is largest on the direction of the main cutting force.

- There is also a deformation component generated by the cutting force on the longitudinal advance direction.

- The deformation component on the radial force direction is also significant.

- Analysis of the proper vibration frequencies of the piece-tool system shows the high frequencies of the proper vibration modes

- Between the first and the tenth proper vibration mode the frequency increases almost 5 times.

\section{References}

[1] Căpățână N., Scule așchietoare (Universitatea Dunărea de Jos, Universitar, Galatiensis, Galați, 2008).

[2] Drăghici G., Tehnologia construcțiilor de mașini (Editura Didactică și Pedagogică, București, 1984).

[3] Dumitru N., Ungureanu A., BMSM elemente finite (Editura Universitaria, 2000).

[4] Picoș C., ș.a., Normarea tehnică pentru prelucrări prin așchiere, vol. I, II (Ed. Tehnică, București, 1979).

[5] Picoș C., ș.a., Proiectarea tehnologiilor de prelucrare mecanică prin așchiere. Manual de proiectare, vol. I + II (Editura Universitas, Chișinău, 1992).

[6] Posea I., Rezistența materialelor. Probleme (Ed. Stiințifică și Enciclopedică, București,1986).

[7] ***, Rocast, Unelte, scule, echipamente industriale 2013/2014, vol. I

[8] Vlase A., ș.a. , Regimuri de așchiere adaosuri de prelucrare și norme tehnice de timp. vol. I+ II (Ed. Tehnică, București, 1983).

[9] ***, Manualul inginerului mecanic (Ed. Tehnică, București, 2000).

[10] ***, Solid Works 2016, software and user manuals. 